\title{
Acute and Chronic Pain: Best Management Approaches in Resource Limited Setting, Cameroon
}

\author{
Njumbo Petronilla Balgah, Mary Bi Suh Atanga \\ Department Nursing, University of Bamenda, Bamenda, Cameroon \\ Email: petronillabalgah@yahoo.com
}

How to cite this paper: Balgah, V.P. and Atanga, M.B.S. (2022) Acute and Chronic Pain: Best Management Approaches in Resource Limited Setting, Cameroon. Pain Studies and Treatment, 10, 1-8. https://doi.org/10.4236/pst.2022.101001

Received: December 9, 2021

Accepted: January 27, 2022

Published: January 30, 2022

Copyright ( 2022 by author(s) and Scientific Research Publishing Inc. This work is licensed under the Creative Commons Attribution International License (CC BY 4.0).

http://creativecommons.org/licenses/by/4.0/

\section{(c) (i) Open Access}

\begin{abstract}
Pain is a common event in many scenarios involving healthcare, from birth to death, in the hospital or outside of it. The overall purpose of this work was to critically review articles on types of pain and options employed in managing pain. Some electronic sources like google scholar, Ovid MEDLINE, PsychINFO, Embase were used to source for information. The articles were reviewed according to the various themes of the topic. From the different sources pain is categorized as acute or chronic with physical, psychological and social characteristics. Effective management of pain utilizes both pharmacologic and non-pharmacologic therapy. Pharmacological therapy employs non-opioids medications. Prolonged or unnecessary use of opioids causes some harmful side effects to the patient. Non-pharmacologic therapy plays a significant role and should be included in the multidisciplinary treatment plan. Nurses are members of the healthcare team who spend most of their time with patients as such they must work in collaboration with other healthcare professionals to facilitate patient's recovery from pain. Healthcare professionals should also make use of internationally recognized guidelines during practice.
\end{abstract}

\section{Keywords}

Acute, Chronic Pain, Management

\section{Introduction}

Pain is a very collective phenomenon observed in medical care environment [1], contributing enormously to morbidity, mortality, disability and a lot of burden in the healthcare system [2] [3]. Pain is often categorized as acute or chronic (See Table 1) where acute has been defined as "the physiologic response and 
Table 1.Types of pain

\begin{tabular}{|c|c|c|c|}
\hline Type of pain & Definition & Pathophysiology & What to handle \\
\hline Acute pain & $\begin{array}{l}\text { It is pain sudden in } \\
\text { onset, may last less than } \\
7 \text { days but often extends } \\
\text { up to } 30 \text { days or } 3 \\
\text { months }\end{array}$ & $\begin{array}{l}\text { It is nociceptive pain that occurs during and after } \\
\text { injury to the viscera, skin tissue or joints. The body } \\
\text { respond by following the pain pathway; } \\
\text { transduction, conduction, transmission, } \\
\text { perception and modulation. }\end{array}$ & $\begin{array}{l}\text { For better management it is } \\
\text { important to assess the cause, pain } \\
\text { intensity duration and what makes } \\
\text { it worst. Medications can be used } \\
\text { to reduce pain intensity while } \\
\text { treating the underlying cause. }\end{array}$ \\
\hline Chronic pain & $\begin{array}{l}\text { It is pain that has lasted } \\
\text { beyond the normal } \\
\text { tissue healing time } \\
\text { (about three months). }\end{array}$ & $\begin{array}{l}\text { Increase in pain intensity may lead to an } \\
\text { exaggerated prolonged reaction of the C-fibre } \\
\text { nociceptors, causing the release of series of } \\
\text { substances into the synaptic gap. This may trigger } \\
\text { a cascade of events leading to a vicious cycle. }\end{array}$ & $\begin{array}{l}\text { Treatment of this kind of pain may } \\
\text { involve a mix physical medical, and } \\
\text { psychological components. }\end{array}$ \\
\hline
\end{tabular}

experience to noxious stimuli that can become pathologic, is normally sudden in onset, time limited, and motivates behaviors to avoid actual or potential tissue injuries." [4] Chronic pain occurs as a result of inadequate management of the latter. As such, every member of the healthcare team must be committed to their role as they help patient's relief pain. Resnick et al. [5], reported that undertreated or untreated pain can been linked to an individuals' overall satisfaction with life. This review seeks to identify different types of approaches used to manage pain in patients within the healthcare setting.

\section{Method}

From the inception of each database, the study made use of electronic searches on MEDLINE ${ }^{\oplus}$ Ovid $^{\oplus}$ and PsycINFO in April 2021. To search the relevant articles in the above search engines we used keyword like "acute pain", "chronic pain", "pain management", "approaches in pain management", "pharmacologic pain management" and "nonpharmacologic pain management". This paper made use of cohort studies, randomized control trials, and cross-sectional studies in its review.

\section{Management}

Generally acute pain is effectively managed by resting the affected part of the body [6] in combination with different approaches such as medication (Table 2) and non-pharmacologic methods (Tables 3-5). The management of chronic pain is as diverse as the causes. It ranges from over-the-counter to prescription therapy to mind/body techniques to acupuncture. As a matter of fact, no single technique can guarantee complete pain relief. Consequently, relief can be effectively achieved through a combination of a series of approaches outlined below (Tables 2-5).

\subsection{Medication}

Generally, pain is best managed following a multidisciplinary approach [7] 
Table 2. Medications used to manage and treat acute and chronic pain.

\begin{tabular}{llll}
\hline Medication & Action & Used & Not Used \\
\hline Codeine & $\begin{array}{l}\text { It is a central nervous system (CNS) } \\
\text { depressant. It changes the way the } \\
\text { body or brain responds to pain. }\end{array}$ & $\begin{array}{l}\text { Painkiller, cough suppressant } \\
\text { and treats mild to severe pain. }\end{array}$ & $\begin{array}{l}\text { Postoperative pain in children, } \\
\text { paralytic Ileus, hypercapnia, acute or } \\
\text { severe bronchial asthma and } \\
\text { respiratory depression. }\end{array}$ \\
Hydrocodone & $\begin{array}{l}\text { Specific CNS opioid receptors for } \\
\text { endogenous compounds with } \\
\text { opioid-like activity and play a role in of opioids. } \\
\text { the analgesic effects of this drug }\end{array}$ & $\begin{array}{l}\text { Use in the management of } \\
\text { severe pain that require the use }\end{array}$ & $\begin{array}{l}\text { Hypersensitivity to hydrocodone, acute } \\
\text { or severe bronchial asthma, respiratory } \\
\text { depression and suspected }\end{array}$ \\
Hydromorphone & $\begin{array}{l}\text { It is an agonist at the mu opioid } \\
\text { peptide receptor/it has a weaker }\end{array}$ & Same as above & $\begin{array}{l}\text { gastrointestinal obstruction } \\
\text { Same as above }\end{array}$
\end{tabular}
affinity at the kappa and delta opioid peptide receptors.
Oxycodone
A semisynthetic opioid with
Used for all types of pain agonistic properties on the different especially in cases where other opioid receptors. It has the strongest medications showed failure affinity for mu-type receptors.

Same as above

Methadone

It is a synthetic opioid, it induces other Manages pain that is

CNS-related pathologies such as trauma, opioid receptors. Methadone activates non-responsive to non-narcotic delirium, etc. Not to be used in the $\mu$-receptors in the same pathway as drugs. Treatment of neonatal the above mentioned opioids. abstinence syndrome conjunction with medications or substances with similar depressant effects

Morphine It binds to the mu-opioid receptor in Moderate to severe pain that the CNS and the PNS to reduce nociceptive transmission.

\section{may be acute or chronic}

It should be avoided in severe respiratory depression, asthma especially in the management of exacerbation cases and in cases of palliative care, in active cancer treatment, and vaso-occlusive pain during sickle cell crisis. previous hypersensitivity reaction and immediately discontinued in the presence of an active reaction.

Acetaminophen

It acts as an inhibitor for the cyclooxygenase (COX) pathways.

Non-steroidal Inhibition cyclooxygenase thus anti-inflammatory leading to lack of eicosanoids such drugs (NSAIDs) as prostaglandins which has an anti-nociception activity.

Antidepressants They increase neurotransmitters serotonin or norepinephrine or both migraine in the synapse.

Tricyclic antidepressants Work by inhibiting the reuptake of Same as above serotonin and norepinephrine.

Musculoskeletal agents

There are two types; antispasmodics and antispasticity. The latter works directly on the skeletal muscle and on the spinal cord. Antispasmodics alters conduction in the CNS hence decrease muscle spasms.

Topical analgesics Its mode of actions is the same as described above, but are applied transdermally.
It is an antipyretic and a non-opioid analgesic agent.

Used to treat pain, fever, and other inflammatory processes. Hypersensitivity to acetaminophen and severe hepatic impairment.

Hypersensitivity to NSAIDs, patients who have undergone coronary artery bypass graft and third trimester pregnancy

Depression, pain, insomnia and Hypersensitivity to antidepressants, cardiovascular disease

Patients with orthostatic hypotension, bundle-branch disease

Severe hepatic and renal dysfunction and patients who have hypersensitivity to these agents.

Management of moderate to severe acute and chronic pain
Patients who have sympathetic systems blocks 
including the use of opioids and non-opioids medications [8] (see Table 2).

\subsection{Restorative Therapies}

Following a comprehensive assessment, restorative therapy can be highly effective in pain management especially if it is part of a multidisciplinary treatment plan [9].

\subsection{Interventional Procedures}

Interventional pain medicine uses minimal invasive procedures and minimizes the use of oral medication. Intervention therapy is offered as part of a comprehensive treatment program [10]. The different interventional therapies are as seen below (See Table 4).

\subsection{Behavioral Health Approaches}

In recent decades, experts have found a strong connection between psychological health and pain [11]. Psychological factors play an important role in a person's response to pain [12]. It affects treatment adherence, disability status, pain chronicity [13]. It increases the risk for physical inactivity related to fear of fear of reinjury, maladaptive coping and psychological distress [14]. Table 5 highlights some of the behavioral health approaches that have been proven to be effective in alleviating pain.

Table 3. Restorative therapies used to manage pain.

\begin{tabular}{|c|c|c|c|}
\hline Therapy & Rationale & Action & Expected outcomes \\
\hline $\begin{array}{l}\text { Therapeutic } \\
\text { exercises }\end{array}$ & $\begin{array}{l}\text { Bodily movements prescribed to help restore } \\
\text { impairment, maintain wellbeing and improve } \\
\text { functioning of the musculoskeletal system. }\end{array}$ & $\begin{array}{l}\text { Passive movements and } \\
\text { active exercises }\end{array}$ & $\begin{array}{l}\text { Improved ambulation, reduce } \\
\text { risk, optimize overall health and } \\
\text { improve fitness and wellbeing }\end{array}$ \\
\hline $\begin{array}{l}\text { Massage } \\
\text { therapy }\end{array}$ & $\begin{array}{l}\text { Inhibits the transmission of noxious stimuli wherein } \\
\text { large nerve fibers are stimulated to alter pain } \\
\text { perception. }\end{array}$ & $\begin{array}{l}\text { Swedish, shiatsu and } \\
\text { deep tissue message. }\end{array}$ & $\begin{array}{l}\text { Lowers blood pressure, decrease } \\
\text { oxygen consumption and muscle } \\
\text { tension. }\end{array}$ \\
\hline Cold therapy & $\begin{array}{l}\text { Cold substances are applied to decrease temperature on } \\
\text { the contact area and adjacent tissues. }\end{array}$ & $\begin{array}{l}\text { Uses bags of crushed ice, } \\
\text { ice massage and cold } \\
\text { compress units etc. }\end{array}$ & Pain relief. \\
\hline Heat therapy & $\begin{array}{l}\text { It activates TPRVI receptors as which modulate the } \\
\text { antinociceptive descending pathway, Resulting to } \\
\text { increase blood flow, metabolism, and connective tissue } \\
\text { elasticity. }\end{array}$ & $\begin{array}{l}\text { Uses heat pads, hot } \\
\text { towels, soft heated packs } \\
\text { etc for massage and } \\
\text { compression. }\end{array}$ & Pain relief. \\
\hline Heat therapy & $\begin{array}{l}\text { It activates TPRVI receptors as which modulate the } \\
\text { antinociceptive descending pathway, Resulting to } \\
\text { increase blood flow, metabolism, and connective tissue } \\
\text { elasticity. }\end{array}$ & $\begin{array}{l}\text { Uses heat pads, hot } \\
\text { towels, soft heated packs } \\
\text { etc for massage and } \\
\text { compression. }\end{array}$ & Pain relief. \\
\hline Bracing & $\begin{array}{l}\text { It uses sticks and other material to uses sticks and other } \\
\text { materials to immobilize part of a body. These objects } \\
\text { limits motion, corrects deformation like scoliosis or } \\
\text { improve functions in certain parts of the body. }\end{array}$ & $\begin{array}{l}\text { Use of lumbar brace, } \\
\text { knee braces }\end{array}$ & $\begin{array}{l}\text { Reduces swelling, stiffness and } \\
\text { pain. }\end{array}$ \\
\hline
\end{tabular}


Table 4. Interventional procedures used to manage pain.

\begin{tabular}{|c|c|c|}
\hline Intervention Procedure & Rationale & Expected Outcome \\
\hline Epidural Steroid Injection & $\begin{array}{l}\text { They function as mechanical and biochemical mediator in pain } \\
\text { relief by inhibiting the release of inflammatory mediators. }\end{array}$ & $\begin{array}{l}\text { Reduced inflammation, thereby } \\
\text { reducing pain. }\end{array}$ \\
\hline $\begin{array}{l}\text { Facet Joint Nerve Block and } \\
\text { denervation injection }\end{array}$ & $\begin{array}{l}\text { It is a common fluoroscopy-guided procedure for facet-related } \\
\text { spinal pain of the neck or low back. }\end{array}$ & Long term effect in relieving pain \\
\hline Cryoneuroablation & $\begin{array}{l}\text { Interventional technique that uses a cryoprobe. It freezes sensory } \\
\text { nerves at the directly on the source of pain. }\end{array}$ & Long term effect in relieving pain. \\
\hline Radiofrequency ablation & $\begin{array}{l}\text { Blocks the transmission of pain signals by ablating certain nerves } \\
\text { that contribute to chronic pain syndrome. }\end{array}$ & Decrease pain intensity. \\
\hline Peripheral Nerve Injection & $\begin{array}{l}\text { Contains a mixture of local anesthetic agents and } \\
\text { anti-inflammatory steroid medication. Effectively blocks the } \\
\text { transmission of pain signals around peripheral nerves }\end{array}$ & Decrease pain intensity \\
\hline
\end{tabular}

Table 5. Behavioral health approaches.

\begin{tabular}{lll}
\hline Approach & Rationale & Expected Outcome \\
\hline Behavioral Therapy & $\begin{array}{l}\text { Uses the principles of operant conditioning in identifying and } \\
\text { reducing maladaptive pain behaviors while increasing } \\
\text { adaptive or "well" behaviors. }\end{array}$ & $\begin{array}{l}\text { It reduces pain behavior and increases } \\
\text { function. }\end{array}$ \\
$\begin{array}{ll}\text { Cognitive Behavioral } \\
\text { Therapy }\end{array}$ & $\begin{array}{l}\text { It uses psychoeducation to relate pain with other psychological It improves over all functioning and } \\
\text { factors like training in a variety of pain coping strategies, } \\
\text { pleasant activity scheduling and activity pacing. }\end{array}$ & reduces maladaptive behavior. \\
$\begin{array}{l}\text { Mindfulness-based } \\
\text { Stress Reduction }\end{array}$ & $\begin{array}{l}\text { Mind-body treatment delivered to a group it uses meditation } \\
\text { to teach individuals how to self-regulate their pain. }\end{array}$ & $\begin{array}{l}\text { It reduces pain intensity; fatigue improves } \\
\text { physical functioning and wellbeing. }\end{array}$ \\
\hline
\end{tabular}

\section{Discussion}

Proper pain management and the way it is assessed remains an important aspect in the provision of quality care. During their stay in the hospital, patents experience pain resulting from different medical procedures, surgical interventions or as a result of the disease condition [15]. Different approaches are used to manage pain in the healthcare facility. They include the single use of pharmacological approach using opioids and NSAIDs or in combination with non-pharmacological approaches.

Pain is an important sensitive nursing indicator, consequently nurses play a central role on how pain is assessed and managed. Unfortunately, there is under-treatment of pain because of social stigma associated with pain, fear of becoming addicted to the use of some pain medications and knowledge deficit demonstrated by some clinicians in the management of pain. There is lack of complete evidence whether increasing knowledge and improving attitudes about pain can influence or improve pain relief.

Some studies reported healthcare professionals intentionally trained to manage pain known as Pain Resource Nurse (PRN) have actually improved quality of pain care [16]. Here, the nurse demonstrates leadership commitment, recog- 
nizes pain management barriers and identifying overcoming strategies, collaborative multidisciplinary teamwork and communication. So far literature on pain management is filled with inadequate knowledge and attitudes about pain and poor practices among healthcare providers, including nurses. Even though the American Society of Pain Management Nurses strongly recommend the use of opioids, ignorance about its use has pushed many who now relate it to addiction [17].

Assessing and managing pain are essential components of nursing practice. Physical therapy, psychotherapy, multidisciplinary rehabilitation in primary, specialized care settings and conservative medical treatment are very effective options for short term treatment of pain [18]. The most important factor to consider when choosing intervention for in pain management is selecting interventions that will provide adequate pain relief by improving quality of life, function, and facilitate recovery while minimizing prescription of opioids and their side effects.

In general literature, pain is principally understood as biological phenomenon. As a result, most studies focus more on clinical or medical approach to pain management. Just like the clinical approach, this study lays emphasis on the extent to which pharmacological and non-pharmacologic approaches are effective cultural competence in managing pain.

\section{Conclusion}

Pain is ubiquitous in pre-clinical and clinical settings and easily verbalized by adults. It is the nurse's responsibility to provide the best management approaches during pain care for different patients. Healthcare providers should consider integrating international guidelines and employ the use of nonpharmacologic interventions as well as nonopioid-based multimodal analgesic regimens when managing patients are with pain. Factors such as astute pain assessment, involving families in decision making, understanding effective treatment and patient advocacy must be considered in order to prevent acute from becoming chronic.

\section{Recommendations}

From the above presentation, the following recommendations can be made:

- Considering the ubiquitous nature of pain in healthcare facilities, all healthcare professionals involved in patients should be offered specialized courses on how to manage pain.

- Healthcare professionals should make use of internationally recognized guidelines in practice.

\section{Implication for Practice}

Healthcare professionals (doctors, nurses and physiotherapist) play an essential role while caring for patients with acute pain. They help prevent its transition to chronic pain. Nurses have the duty to advocate for patients. They much collabo- 
rate with other members of the healthcare team to design and administer the most effective treatment and care that will restore physical, emotional, and social health, facilitate recovery and lead to the best possible outcomes for patients with pain. They must involve and respect both patients and their families as partners in decisions regarding care.

\section{Conflicts of Interest}

The authors declare no conflicts of interest regarding the publication of this paper.

\section{References}

[1] Sallum, A.M.C., Garcia, D.M. and Sanches, M. (2012) Acute and Chronic Pain: A Narrative Review of the Literature. Acta Paulista de Enfermagem, 25, 150-154. https://doi.org/10.1590/S0103-21002012000800023

[2] Furlan, A.D., Pennick, V., Bombardier, C., et al. (2009) Updated Method Guidelines for Systematic Reviews in the Cochrane Back Review Group. Spine (Phila Pa 1976), 34, 1929-1941. https://doi.org/10.1097/BRS.0b013e3181b1c99f

[3] Nielsen, S., Degenhardt, L., Hoban, B., et al. (2016) A Synthesis of Oral Morphine Equivalents (OME) for Opioid Utilisation Studies. Pharmacoepidemiology and Drug Safety, 25, 733-737. https://doi.org/10.1002/pds.3945

[4] U.S. Preventive Services Task Force (2018) Methods and Processes. https://www.uspreventiveservicestaskforce.org/Page/Name/methods-and-processes

[5] Resnick, B., Boltz, M., Galik, E., Holmes, S., Vigne, E., Fix, S. and Zhu, S. (2019) Pain Assessment, Management, and Impact among Older Adults in Assisted Living. Pain Management Nursing, 20, 192-197. https://doi.org/10.1016/j.pmn.2019.02.008

[6] John, L.Z., Burke, A.L. and Glass, R.M. (2008) Acute Pain Treatment. JAMA, 299, 128. https://doi.org/10.1001/jama.299.1.128

[7] Kaye, A.D., Cornett, E.M., Hart, B., et al. (2018) Novel Pharmacological Nonopioid Therapies in Chronic Pain. Current Pain and Headache Reports, 22, 31.

https://doi.org/10.1007/s11916-018-0674-8

[8] Nicol, A.L., Hurley, R.W. and Benzon, H.T. (2017) Alternatives to Opioids in the Pharmacologic Management of Chronic Pain Syndromes: A Narrative Review of Randomized, Controlled, and Blinded Clinical Trials. Anesthesia \& Analgesia, 125, 1682-1703. https://doi.org/10.1213/ANE.0000000000002426

[9] U.S. Department of Health and Human Services (2019, May) Pain Management Best Practices Inter-Agency Task Force Report: Updates, Gaps, Inconsistencies, and Recommendations.

[10] Bicket, M.C., Chakravarthy, K., Chang, D. and Cohen, S.P. (2015) Epidural Steroid Injections: An Updated Review on Recent Trends in Safety and Complications. Pain Management, 5, 129-146. https://doi.org/10.2217/pmt.14.53

[11] Bushnell, M.C., Ceko, M. and Low, L.A. (2013) Cognitive and Emotional Control of Pain and Its Disruption in Chronic Pain. Nature Reviews Neuroscience, 14, 502-511. https://doi.org/10.1038/nrn3516

[12] Kellezi, B., Coupland, C., Morriss, R., et al. (2017) The Impact of Psychological Factors on Recovery from Injury: A Multicentre Cohort Study. Social Psychiatry and Psychiatric Epidemiology, 52, 855-866. https://doi.org/10.1007/s00127-016-1299-Z 
[13] Gatchel, R.J., McGeary, D.D., McGeary, C.A. and Lippe, B. (2014) Interdisciplinary Chronic Pain Management: Past, Present, and Future. American Psychologist, 69, 119-130. https://doi.org/10.1037/a0035514

[14] Gatzounis, R., Schrooten, M.G.S., Crombez, G. and Vlaeyen, J.W.S. (2012) Operant Learning Theory in Pain and Chronic Pain Rehabilitation. Current Pain and Headache Reports, 16, 117-126. https://doi.org/10.1007/s11916-012-0247-1

[15] Gregory, J. and McGowan, L. (2016) An Examination of the Prevalence of Acute Pain for Hospitalized Adult Patients: A Systematic Review. Journal of Clinical Nursing, 25, 583-598. https://doi.org/10.1111/jocn.13094

[16] Ferrell, B.R., Grant, M., Ritchey, K.J., Ropchan, R. and Rivera, L.M. (1993) The Pain Resource Nurse Training Program: A Unique Approach to Pain Management. Journal of Pain Symptom Management, 8, 549-556.

https://doi.org/10.1016/0885-3924(93)90084-9

[17] van Booked, L.C., Brouwers, E.P., van Weeghel, J. and Garretsen, H.F. (2015) Comparing Stigmatizing Attitudes towards People with Substance Use Disorders between the General Public, GPs, Mental Health and Addiction Specialists and Clients. International Journal of Social Psychiatry, 61, 539-549. https://doi.org/10.1177/0020764014562051

[18] Pfeifer, A.-C., Penedo, J.M.G., Ehrenthal, J.C., Neubauer, E., Amelung, D., Schroeter, C. and Schiltenwolf, M. (2018) Impact of Attachment Behavior on the Treatment Process of Chronic Pain Patients. Journal of Pain Research, 11, 2653-2662. https://doi.org/10.2147/JPR.S165487 